\title{
GONAD REMATURATION ON Pangasionodon hypophthalmus FEMALE THROUGH INJECTION OF PREGNANT MARE SERUM GONADOTROPIN AND HUMAN CHORIONIC GONADOTROPIN
}

\author{
Evi Tahapari”, Jadmiko Darmawan, Raden Roro Sri Pudji Sinarni Dewi, \\ Wahyu Pamungkas, and Huria Marnis
}

Research Institute for Fish Breeding, Sukamandi, West Java

(Received 17 January 2014; Accepted 25 April 2014)

\begin{abstract}
The success of spawning is influenced by internal and external factors. One of the factors that affect the variability of Pangasianodon hypophthalmus female reproductive is the change of seasons that cause disrupted continuity of the seed availability, especially in the dry season. In the present study, combination of PMSG (pregnant mare serum gonadotropin) + HCG (hormone chorionic gonadotropin) hormone injections was done to induce gonad development. The treatments in this study were without hormone injections as control (A), injection of PMSG $10 \mathrm{lU} / \mathrm{kg}+$ HCG $10 \mathrm{lU} / \mathrm{kg}$ (B), and injection of PMSG $20 \mathrm{IU} / \mathrm{kg} \mathrm{HCG}+10 \mathrm{IU} / \mathrm{kg}$ (C). Injections were conducted at intervals of two weeks as many as six times. The results showed that gonad maturation generally occurs 2- 4 weeks after estradiol- $17 \beta$ peak. PMSG + HCG hormone injections gave a significant effect on increasing the quantity and quality of eggs production. The fecundity in the A, B, C treatments, were $233,700 \pm 220,676$; $300,305 \pm 24,581$ and $488,433 \pm 142,228$; respectively. Number of larvae produced from the A, B, C treatments, were 156,979 $\pm 170,838 ; 229,997 \pm 18,081$ and $362,713 \pm 101,850$; respectively. Combination of PMSG $20 \mathrm{IU} / \mathrm{kg}+\mathrm{HCG} 10 \mathrm{IU} / \mathrm{kg}$ hormone injection gave the best result on fecundity and the number of larvae production.
\end{abstract}

KEYWORDS: PMSG, HCG, gonadal development, Pangasianodon hypophthalmus

\section{INTRODUCTION}

Striped catfish (Pangasianodon hypophthalmus) is one of the farming fish that become priority to develop into industrial scale in Indonesia. Increase the production can only be achieved through aquaculture. The striped catfish spawning technology has been well adopted by the farmer. One of the constraints faced by farmer is depletion of quantity and quality of egg after rematuration. Hormone manipulation can be applied to overcome this problem, hence fish reproduction, through hormonal injection to accelerate and stimulate gonad maturation and ovulation.

In general, reproduction in female fish involves two main processes, i.e. vitellogenesis and maturation. Vitellogenesis is a gradual process of egg development through the yolk formation. Maturation is the final egg maturation process. Vitellogenesis and maturation process are regulated by gonadotropin hormone; folicle stimulating hormone (FSH) in-

\# Corresponding author. Research Institute for Fish Breeding

JI. Raya 2 Sukamandi, Subang 41256, West Java, Indonesia. Telp.: +62 260520500

E-mail: evitahapari@yahoo.co.id 
volved in vitellogenesis, while luteinizing hormone (LH) stimulate maturation and ovulation (Sun \& Pankhurst, 2004). There are several types of hormones that can be used to stimulate gonad development, including PMSG (pregnant mare serum gonadotrophin) and HCG (human chorionic gonadotrophin). PMSG primarily function stimulates follicle growth and maturing follicles that are formed (Basuki, 1990). PMSG has dominant element of FSH and little $\mathrm{LH}$ (Basuki, 1990). In medaka (Oryzias latipes), the use of $100 \mathrm{IU} / \mathrm{mL}$ PMSG in vitro against several ovarian able to stimulate production of estradiol- $17 \beta$, observed at the age of 32 days prior to spawning. This shows that PMSG induce follicular aromatase activity through adenylate cyclase- cAMP system (Nagahama et al., 1991). HCG is the kind of hormone that is used to stimulate ovulation in fish (Park, 2002). HCG could induce ovulation in several fish species such as channel catfish (Ictalurus punctatus), goldfish (Carassius auratus), striped bass (Morone saxatilis), and redear sunfish (Lepomis microlopus) (reviewed by Park, 2002). LH element is dominant in HCG.

PMSG and HCG is chorionic hormone that has double biology activity such as FSH and LH (Hafez et al., 2000; Legendre, 1986). In the present study, combination of PMSG and HCG were applied to induce gonad rematuration on striped catfish. FSH activity that is dominant in PMSG expected could induce vitellogenesis, while LH activity that was dominant in HCG was expected could increase final oocyte maturation and ovulation on female striped catfish. Observation of egg development, estradiol$17 \beta$ hormone profile, and larvae production were done to determine the effect of both hormones.

\section{MATERIALS AND METHODS}

\section{Time and Location of Study}

This study was conducted in the experimental ponds at Institute for Fish Breeding in Sukamandi, Subang, West Java, for the periods of four months.

\section{Fish Used in The Study}

Nine females with aged of 2- 3 years and an average weight of 2,393.16 $\pm 353.94 \mathrm{~g}$ were used in this study. The fishes were divided into three groups. Three females paired with three males were placed in the net cage with size of $5 \mathrm{~m} \times 3 \mathrm{~m} \times 1.25 \mathrm{~m}$, that were set up in
$6,000 \mathrm{~m}^{2}$ of earthen pond. Female broodstock that used in this study has previously spawned. Microchip tag was inserted into dorsal muscles to facilitate observation. The fish were fed with commercial pellet (36\%protein content), twice a day at a ratio of $2 \%$ per biomass.

\section{Hormone Treatment}

Combination of PMSG and HCG, and each dosage in this experiment are as follow:

A. Without hormone injections as control

B. PMSG $10 \mathrm{lU} / \mathrm{kg}+\mathrm{HCG} 10 \mathrm{lU} / \mathrm{kg}$ of fish

C. PMSG $20 \mathrm{IU} / \mathrm{kg}+\mathrm{HCG} 10 \mathrm{IU} / \mathrm{kg}$ of fish

PMSG and HCG were mixed and then injected intramuscularly on either side of the dorsal fin with the injection angle $\pm 45^{\circ}$. Injections were conducted every two weeks as many as six times.

\section{Blood and Eggs Collection}

Blood and egg were collected every two weeks for 16 weeks. Blood samples were taken from the base of caudal fin as much as $3 \mathrm{~mL}$ using a syringe containing anticoagulants (heparin). Prior to blood sampling, fish was anesthetized with 2-phenoxyethanol $0.5 \mathrm{ppt}$. Samples of eggs were retrieved using cannulation from each fish and fixed into $70 \%$ ethanol. Fifty eggs from each female were measured for its diameter using a microscope equipped with an ocular micrometer. By the time, when an average diameter of eggs reach sizes above $0.9 \mathrm{~mm}$, then the fish were induced by HCG and ovaprim to stimulate ovulation. The fish were stripped for fertilization.

\section{Estradiol- 17 $\beta$ Measurements}

Blood samples were centrifuged at 3,000 rpm for 10 minutes. Plasma was separated from the sediment and stored at $-20^{\circ} \mathrm{C}$. Measurement of plasma estradiol- $17 \beta$ was performed by ELISA using a commercial kit DRG Estradiol ELISA EIA- 2693. Test procedure was performed by following the test kit manual. Sample concentration was determined by absorbance at $450 \mathrm{~nm}$. Average absorbance values were calculated for each set of standards, controls, and sample. Standard curve was constructed by plotting the mean absorbance obtained from each standard against its concentration. The mean absorbance value for each sample was calculated by determining the corresponding concentration from the standard curve. 


\section{Fecundity, Fertilization Rate, Hatching} Rate, and Larvae Production

Fecundity $(F)$ was measured on spawned female. Eggs were obtained by stripping female abdomen. The formula used to calculate the fecundity was as follows:

$$
\mathrm{F}=\frac{\text { Number of egg sample }}{\text { Sample weight }(\mathrm{g})} \times \text { Egg total weight }(\mathrm{g})
$$

Fertilization rate (FR) was observed at 3- 5 hours after fertilization. The formula used to calculate the fertilization rate was:

$$
\mathrm{FR}=\frac{\text { Number of fertilized egg }}{\text { Total number of egg }} \times 100 \%
$$

Hatching rate (HR) was observed at 20- 24 hours after fertilization (after all eggs hatch). The formula used to calculate the hatching rate was:

$$
\mathrm{HR}=\frac{\text { Number of hatching egg }}{\text { Number of fertilized egg }} \times 100 \%
$$

Production of larvae from each spawning female was calculated after all the eggs are hatched. Number of Iarvae was calculated using the formula:

$$
\text { Number of larvae }=\mathrm{HR} \times \mathrm{FR} \times \mathrm{F}
$$

where:

$$
\begin{aligned}
& \mathrm{HR}=\text { Hatching rate } \\
& \mathrm{FR}=\text { Fertilization rate } \\
& \mathrm{F}=\text { Fecundity }
\end{aligned}
$$

\section{RESULTS AND DISCUSSION}

Egg Development and Estradiol- 17 $\beta$ Hormonal Profile on Striped Catfish

Egg diameter and estradiol- $17 \beta$ concentration showed variation between treatments (Figure 1 ). In the control (A), all female reached gonad maturation at $6^{\text {th }}$ weeks. After 6 - 8 weeks, all female reached gonad rematuration. In female group treated with combination of PMSG $10 \mathrm{IU} / \mathrm{kg}+\mathrm{HCG} 10 \mathrm{IU} / \mathrm{kg}$ (B) hormone injections, gonad maturation occurred at $12^{\text {th }}$ and $14^{\text {th }}$ week. In female group treated with combination of PMSG $20 \mathrm{IU} / \mathrm{kg}$ + HCG $10 \mathrm{IU} / \mathrm{kg}$ (C) hormone injections, one female reached gonad maturation at $6^{\text {th }}$ week and gonad rematuration occurred at $12^{\text {th }}$ week, while the other two females reached gonad maturation at $12^{\text {th }}$ week. The control fish reached maturity faster than treatment fish. It is suggested, that the treatment fish may be stressed during injection.

Concentrations of estradiol- $17 \beta$ hormone in plasma increased with increasing size of the egg. In general, the striped catfish which received treated hormone injection reached gonad maturation 2- 4 weeks after estradiol- $17 \beta$ hormone reached peak concentration (Figure $1)$.

\section{Fecundity, Fertilization Rate, Hatching} Rate, and Larvae Production

Combination of PMSG and HCG hormone injections on female broodstock gave significant effect on the production of eggs and larvae of striped catfish (Table 1). In A group, all female reached gonad maturation at $6^{\text {th }}$ week, but the quantity and quality of produced eggs were varied. Of three females were observed, the first female failed to reach ovulation, the second female produced larvae in small amounts (<100,000), and the other female produced larvae in large numbers $(>150,000)$. At $12^{\text {th }}$ week, one female produced larvae in small amounts and the two other produced large numbers of larvae. In B group, all female reached gonad maturation at $12^{\text {th }}$ week. All female which were induced by combination of PMSG + HCG hormones produced highly numbers and good quality of eggs. In $\mathrm{C}$ group, one female reached gonad maturation at $6^{\text {th }}$ and $12^{\text {th }}$ week, while the other two females reached gonad maturation at $12^{\text {th }}$ week. Female in C group produced the highest number of eggs and larvae.

\section{Discussion}

Variation of eggs size were observed in all treatments indicated that egg development in gonad and vitellogenesis processing to lead maturation level. Vitellogenesis is absorption of vitellogenin proteins process by egg and change it into the egg yolk proteins resulting in female gonads development to end maturation (Glasser et al., 2004; Lubzens et al., 2010). Vitellogenin synthesis in striped catfish was stimulated by estradiol- $17 \beta$. Estradiol may stimulate vitellogenesis process that is secreted by the gonads of female fish during the vitellogenesis period. When linked with the development of egg size on all treatment, the egg diameter reached the highest size after 2 - 4 weeks of estradiol- $17 \beta$ concentrations peaked. Estradiol- $17 \beta$ level changes were as- 


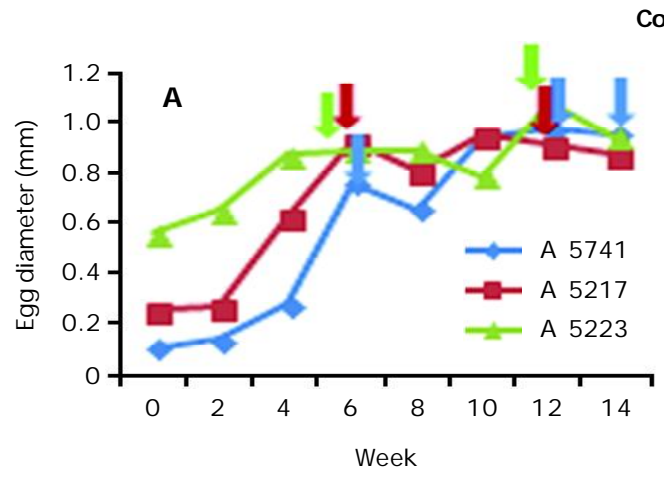

Control
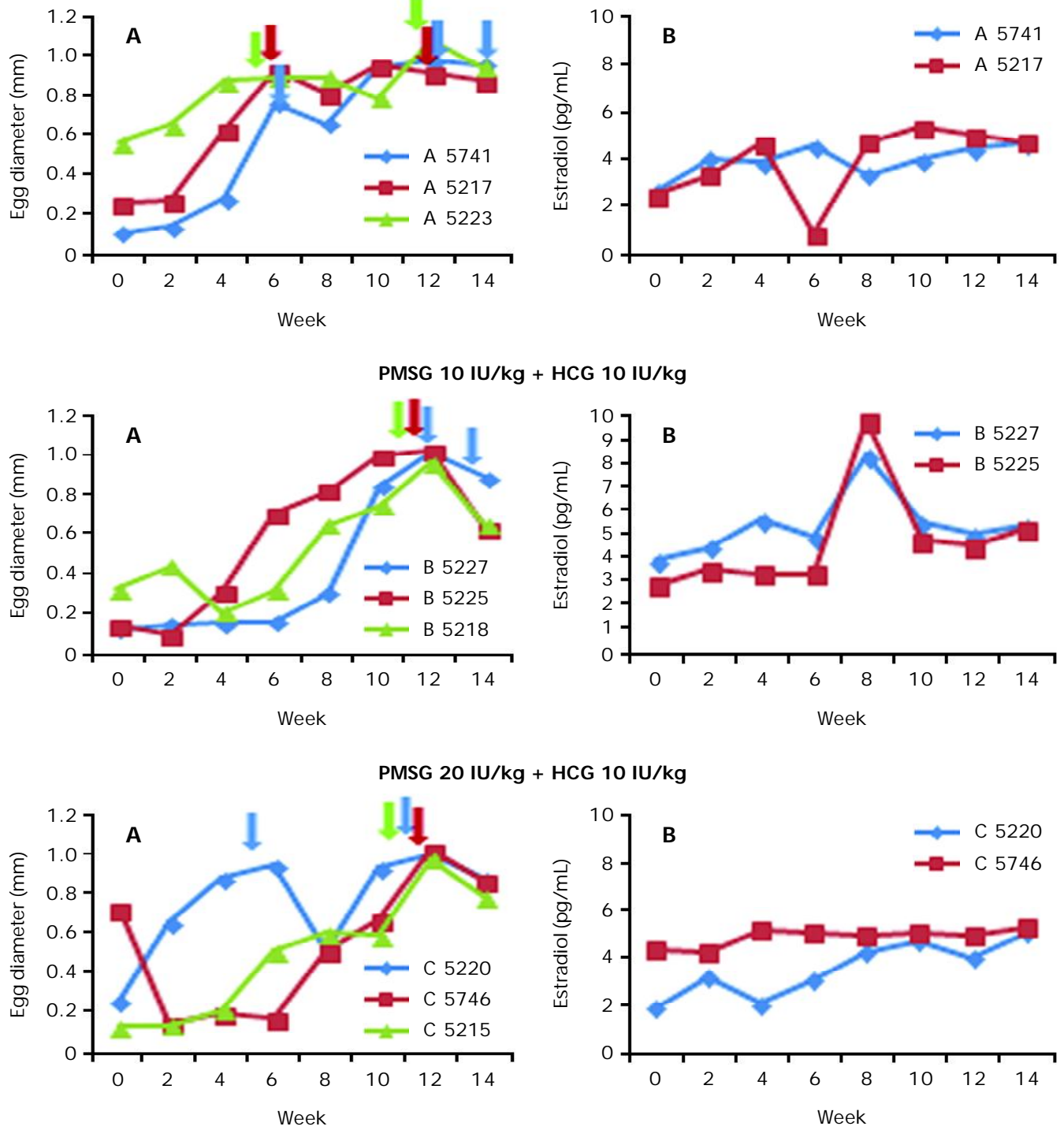

Figure 1. Egg development (A) and estradiol- $17 \beta$ hormone profile (B) in Pangasianodon hypophthalmus which were induced by combination of PMSG and HCG hormone injection (Arrows showed fish were spawned)

sociated with the development of egg and gonadosomatic index increased (Lee \& Young, 2002). The phenomenon of the peak concentrations of estradiol- $17 \beta$ that occurred during vitellogenesis and then decreased sharply also occurs in Chalcaburnus tarichi (Unal et al., 2006).

Injection of PMSG + HCG hormone combination on striped catfish female increased quantity and quality of eggs. PMSG and HCG hormone are known to have dual activity, i.e. FSH and LH (Hafez et al., 2000). FSH is responsible for the development of egg (vitelogenesis), while LH triggers egg maturation. FSH stimulates the theca cells through the CAMP system to produce testostosterone and subsequently converted to estradiol- $17 \beta$ whose presence leads to the development of egg. 
Gonad rematuration on Pangasionodon hypophthalmus female ... (Evi Tahapari)

Table 1. Fecundity, fertilization rate, hatching rate, and larval production on Pangasianodon hypophthalmus induced by combination of PMSG and HCG hormone injection

\begin{tabular}{|c|c|c|c|c|c|}
\hline Treatments & $\begin{array}{c}\text { Fecundity } \\
\text { (eggs) }\end{array}$ & $\begin{array}{l}\text { FR } \\
(\%)\end{array}$ & $\begin{array}{l}\text { HR } \\
(\%)\end{array}$ & $\begin{array}{c}\text { Larval } \\
\text { production }\end{array}$ & Annotation \\
\hline \multicolumn{6}{|l|}{ Control } \\
\hline A 5223 & 0 & 0 & 0 & 0 & $\begin{array}{c}\text { Spawning } 1 \\
\text { (Failed ovulation) }\end{array}$ \\
\hline A 5223 & 35,834 & 85.9 & 37.1 & 11,425 & Spawning 2 \\
\hline A 5741 & 90,364 & 52.4 & 57.2 & 27,102 & Spawning 1 \\
\hline A 5741 & 484,538 & 88.3 & 72.0 & 307,960 & Spawning 2 \\
\hline A 5741 & 21,812 & 46.6 & 0 & 0 & $\begin{array}{c}\text { Spawning } 3 \\
\text { (Failed to hatch) }\end{array}$ \\
\hline A 5217 & 261,744 & 83.6 & 89.4 & 195,625 & Spawning 1 \\
\hline A 5217 & 507,908 & 92.0 & 85.5 & 399,760 & Spawning 2 \\
\hline Average $\pm S D$ & $233,700 \pm 220,676$ & $74.8+19.9$ & $56.9 \pm 33.9$ & $156,979 \pm 170,838$ & \\
\hline \multicolumn{6}{|c|}{ PMSG 10 IU/ kg + HCG 10 IU/ kg } \\
\hline B 5218 & 289,788 & 100 & 85.3 & 247,082 & Spawning 1 \\
\hline B 5225 & 336,528 & 99.3 & 67.9 & 226,987 & Spawning 1 \\
\hline B 5227 & 281,998 & 100 & 85.3 & 240,000 & Spawning 1 \\
\hline B 5227 & 292,904 & 93.3 & 75.3 & 205,920 & Spawning 2 \\
\hline Average $\pm S D$ & $300,305 \pm 24,581$ & $98.2 \pm 3.3$ & $78.5 \pm 8.5$ & $229,997+18,081$ & \\
\hline \multicolumn{6}{|c|}{ PMSG 20 IU/ kg + HCG 10 IU/ kg } \\
\hline C 5220 & 417,544 & 79.6 & 94.2 & 313,200 & Spawning 1 \\
\hline C 5220 & 662,150 & 92.8 & 77.4 & 475,421 & Spawning 2 \\
\hline C 5215 & 336,528 & 98.6 & 74.6 & 247,542 & Spawning 1 \\
\hline C 5746 & 537,510 & 98.0 & 78.7 & 414,688 & Spawning 1 \\
\hline Average $\pm S D$ & $488,433 \pm 142,228$ & $92.3 \pm 8.8$ & $81.2 \pm 8.8$ & $362,713 \pm 101,850$ & \\
\hline
\end{tabular}

PMSG primarily function stimulates follicle growth and maturing follicles that are formed (Basuki, 1990) while HCG function stimulates ovulation in fish (Park, 2002).

Good quality eggs have the ability to be fertilized and develop into a normal embryo. Quality of fish eggs is influenced by several factors, such as nutrition, environment, treatment including induction of spawning, egg ovulated, gametes handling, and stress (Bobe \& Labbe, 2010). Experts suggested that the developmental biology of fish egg quality is determined by the presence of intrinsic factor, i.e. genes, maternal mRNA transcription, nutrient content in the yolk, and hormonal status, all of which are available in the fish body
(Brooks et al., 1997). Further Bobe \& Labbe (2010) argued that there are several estimators that can be used to assess quality of fish eggs, such as determined by the size and appearance of the unfertilized eggs. Fertilization success was determined by cell division after fertilization, hovering capability for pelagic eggs, and embryos abnormality. In this study, injection of PMSG $20 \mathrm{lU} / \mathrm{kg}$ + HCG $10 \mathrm{lU} / \mathrm{kg}$ hormone in the striped catfish female provide the best effect on the quality of the eggs produced are characterized by an increased degree of fertilization and hatching.

The increasing of egg quantity and quality from treated female was suggested as an impact of PMSG and HCG injection. Induction of 
PMSG and HCG on female gonad increased fecundity and larval production (Table 1), that showed the role of exogenous hormones on egg development and maturation.

\section{CONCLUSION}

Combination of PMSG $20 \mathrm{IU} / \mathrm{kg}+$ HCG 10 IU/ kg hormone injection gave the best effect to increase fecundity and larval production on striped catfish.

\section{ACKNOWLEDGMENTS}

This study was funded by Ministry of Marine Affairs and Fisheries of Indonesia. The author is thankful to Kamlawi, Arsyad Tirta Subangkit, Sudarto, and Ikhsan Aulia, for the technical assistance in this experiment.

\section{REFERENCES}

Basuki, F. 1990. Pengaruh kombinasi hormon PMSG dan HCG terhadap ovulasi Clarias gariepinus (Burchell). Tesis. Fakultas Pascasarjana, Institut Pertanian Bogor, 31 pp.

Bobe, J. \& Labbé, C. 2010. Egg and sperm quality in fish. General and Comparative Endocrinology, 165: 535- 548.

Brooks, S., Tyler, C.R., \&Sumpter, J.P. 1997. Egg quality in fish: what makes a good egg?. Fish Biology and Fisheries, 7: 387-416.

Glasser, F., Mikolajczyk, T., Jalabert, B., Baroiller, J.F., \& Breton, F. 2004. Temperature effects along the reproductive axis during spawning induction of grass carp (Ctenopharyngodon idella). General and Comparative Endocrinology, 136: 171- 179.

Hafez, E.S.E., Jainudeen, M.R., \& Rosnina, Y. 2000. Hormones, growth factors, and reproduction. In Hafez, B. \& Hafez, E.S.E. (Eds.), Reproduction in Farm Animals. $7^{\text {th }}$
Ed. USA. Lippincott Williams \& Wilkins. p. 33- 54.

Lee, W.K. \& Young, S.W. 2002. Relationship between ovarian development and serum levels of gonadal steroid hormones, and induction of oocyte maturation and ovulation in the cultured female Korean spotted sea bass Lateolabrax moculatus (Jeomnong- eo). Aquaculture, 207: 169- 183.

Legendre, M. 1986. Seasonal changes in sexual maturity and fecundity, and HCGinduced breeding of the catfish, Heterobranchus longifilis Val. (Clariidae), reared in Ebrie Lagoon (Ivory Coast). Aquaculture, 55: 201- 213.

Lubzens, E., Young, G., Bobe, J., \& Cerdá, J. 2010. Oogenesis in teleosts: How fish eggs are formed. General and Comparative Endocrnology, 165: 367- 389.

Nagahama, Y., Matsuhisa, A., Iwamatsu, T., Sakai, N., \& Fukada, S. 1991. A mechanism for the action of pregnant mare serum gonadotropin on aromatase activity in the ovarian follicle of the medaka, Oryzias latipes. Journal of Experimental Zoology, 259: 53- 58.

Park, I.S. 2002. Induction of ovulation by HCG, LHRHa and carp pituitary in Rhynchocypr is oxycephalus (Sauvage and Dabry). Asian Fisheries Science, 15: 387- 393.

Sun, B. \& Pankhurst, N.W. 2004. Patterns of oocyte growth, vitellogenin and gonadal steroid concentrations in greenback flounder. Journal of Fish Biology, 64: 1,399- 1,412.

Unal, G., Karakisi, H., \& Mahmut, E.L.P. 2006. Levels of some ovarian hormones in the pre- and post spawning periods of Chalcaburnus tarichi Pallas 1811, and the postovulatory structure of follicles. Turkish Journal of Animal Science, 30: 427- 434. 